\title{
Prevalence of Pingueculum and Pterygium Among Adults at an Outreach in an Upland Community in Rivers State, Nigeria
}

\author{
Ireju Onyinye Chukwuka ${ }^{1 *}$ and Henrietta Odiri Nwachukwu ${ }^{2}$ \\ ${ }^{1}$ Department of Ophthalmology, University of Port Harcourt, Nigeria \\ ${ }^{2}$ Department of Ophthalmology, University of Port Harcourt Teaching Hospital, Nigeria
}

*Corresponding author: Ireju Onyinye Chukwuka, Department of Ophthalmology, University of Port Harcourt, Nigeria.

Received Date: February 20, 2020

Published Date: March 02, 2020

\section{Abstract}

Aim: To determine the prevalence of pingueculum and pterygium among adults in Eneka community and to access the demographic profile and associated ocular findings in affected adults.

Methodology: Teaming up with other volunteers for a free medical outreach gave us the opportunity to evaluate the ocular health status of this semi-urban population. A cross sectional study was conducted in which each subject had a detailed ocular examination including visual acuity, anterior segment evaluation with pen-torch, funduscopy, tonometry and refraction where indicated. Collected data was subsequently analyzed using Epi-info version 7.

Results: One hundred adults were screened for Pingueculum and Pterygium comprising 28(28\%) male and 72(72\%) females. Three (3\%) of them had Pingueculum while five (5\%) had Pterygium. The mean age was 31.1 13.3 years. Most of the pterygia (80\%) were unilateral and most $(80 \%)$ of the participants had normal visual acuity $(6 / 5-6 / 18)$ while all of them had normal intraocular pressures.

Conclusion: Pingueculum and Pterygium are relatively uncommon in Eneka community.

Keywords: Eneka community; Pingueculum; Pterygium; Nigeria

\section{Introduction}

A pterygium is a wing shaped hyperplastic and fibrovascular growth of the conjunctiva encroaching onto the cornea. Liang et al suggested that both cell apoptosis and cell proliferation processes are strongly associated with the development and progression of pterygium [1]. It is a cause of visual impairment and blindness if untreated [2]. Pingueculum is a small yellowish nodule often bilateral and usually located nasally by the limbus [3,4]. Over 200 million people have pterygium globally with a rising prevalence with increasing age [5]. Reports indicate a very wide range in its prevalence from $0.7 \%$ to $38.7 \%$ in various locations [6,7]. Revzan in a meta-analysis found the global prevalence of pterygium to be $12 \%$ [8]. In Nigeria the prevalence varies from $2.8 \%$ to $19.3 \%$ [911]. The prevalence of pingueculum also varies in different parts of the world. In India, Asokan et al observed a pterygium preva lence of $11.3 \%$ [12,13]. In Iran it was $61 \%$ [5]. In China $75.57 \%$ [14] in Spain 47.9\% [15] and in Latin America it was 11\% and 7\% respectively in Columbia and Choco [16] in Argentina 32.1\% [17] and among a group of welders in Ile-Ife, Nigeria it was pterygium $17.5 \%$ [12] and pingueculum $50.1 \%$.

The definitive cause of pterygium is unknown but it is believed to result from conjunctival and corneal trauma caused by exposure to ultraviolet radiation, oxidative stress, dust particles, genetic, environmental, infective and immunologic factors [18] Pingueculum has similar causative factors as pterygium and almost always a precursor to pterygium [4]. Histopathologically pterygium is like pingueculum (they both exhibit squamous metaplasia and surface keratinization), but the pterygium in addition is fibrovascular and encroaches on the cornea. 
Pterygium is more common in males than females in locations where more males are engaged in outdoor activities [19] and it also occurs more commonly in rural areas. It may be unilateral or bilateral occurring more often nasally than temporally because of light passing medially through the cornea and focusing on the nasal limbus [20]. It is almost always preceded by pingueculum [21,22] and is associated with varying degrees of discomfort such as recurrent inflammation with redness, foreign body sensation and blurring of vision [23]. Most of the available data on prevalence of Pterygium in Nigeria are from hospital-based studies or screening of high-risk groups. This study is therefore necessary to find out the prevalence of pterygium in a semi-urban population.

\section{Methodology}

A cross sectional study was carried out at a free medical outreach at Eneka, a suburb close to Port Harcourt in December,2017. The team was made up of two Ophthalmologists, two Optometrists, one Ophthalmic Nurse, and six others who registered the subjects, carried out visual acuity testing and administered medication.

Eneka is a semi -urban community about 7 kilometers from Port Harcourt. It is located at an elevation of 416 meters above sea level and is one of the invaded communities in Ikwerre. Prior to oil exploration activities in 1960, the predominant occupation of the people was farming and trading. A minimum sample size of 84 was obtained by the Right Size software using the 95\% confidence level, confidence limits of $4 \%$ and proportion of 3.6\%. [1] Non-response rate adjustment yielded a final sample size of 100 .

Before the commencement of the exercise, a prep talk was given to the people by one of the Ophthalmologists on the necessity for periodic ocular screening in our adult population. One hundred people among those seen were included in the study. The exclusion criteria were age less than 20 years and a history of ocular surgery. A detailed ocular examination was done including visual acuity, anterior segment examination and funduscopy. The visual acuity was done under day light using a Snellen's chart at 6 meters and then re- peated using a pin- hole. Each eye was tested separately then both eyes together. External ocular examination was done with a pentorch, but the absence of a slit-lamp limited a detailed examination of the pterygium head and accurate staging. None of the pterygia was in stage 4 , only one appeared to be in stage 3 , while the other four were in stages 1 and 2 (two in each stage). Funduscopy was done using Welch Allyn direct ophthalmoscopes while intraocular pressures were measured using a Keeler air-puff tonometer. Refraction was limited by the unavailability of a suitable room for retinoscopy and/or an autorefractor, so only presbyopic corrections were given. People requiring further medical therapy or ocular surgery were referred to the government-owned specialist and teaching hospitals.

Data entry was done using Excel spreadsheet. Data on age were expressed in the following categories; <30, 30-39, 40-49, 50-59, $60-69$ and $\geq 70$ years. Visual acuity was categorized as $>6 / 18,6 / 18$ $-6 / 36$ and $<6 / 36$ while IOP was categorized as $0-15 \mathrm{mmHg}$ and 16-30 mmHg. Data analysis was done using Epi-Info version 7. Data were expressed as frequencies and percentages. Confidence intervals were calculated at the $95 \%$ level.

\section{Results}

\section{Demographics}

The study was carried out on one hundred (100) subjects with an age range of 28 to 59 years (mean age $=31.1 \pm 13.3$ years). Twenty-eight of the subjects (28.0\%) were males while 72 (72.0\%) were females. Only $5 \%$ of them had pterygium (Table 1); $80 \%$ of the pterygia were unilateral, $60 \%$ occurred in the $40-49$ years age group (Table 3) and $80 \%$ of the subjects had normal visual acuity. For pinguecula, $3 \%$ of the study population had pingueculum (Table 1 ), it was commoner in females, commoner in the 40-49 years age group, was unilateral in $2 / 3$ of cases (Table 2) and all the subjects had normal visual acuity and intraocular pressure levels.

(Table 1,2\&3)

Table 1: Prevalence of Pingueculum and Pterygium ( $N=100)$.

\begin{tabular}{|c|c|c|}
\hline Variable & Frequency & Prevalence (95\% Confidence Interval) \\
\hline Pingueculum $(\mathrm{N}=100)$ & 3 & $3.0 \%(0.8 \%-7.9 \%)$ \\
\hline Pterygium $(\mathrm{N}=100)$ & 5 & $5.0 \%(1.9 \%-10.7 \%)$ \\
\hline
\end{tabular}

Table 2: Demographic and eye characteristics of respondents with Pingueculum (N=3).

\begin{tabular}{|c|c|c|}
\hline Demographic variables & Frequency & Percentage (\%) \\
\hline \multicolumn{3}{|c|}{ Age Category } \\
\hline $40-49$ years & 2 & 36.7 \\
\hline $50-59$ years & 1 & 33.3 \\
\hline Male & 1 & 66.7 \\
\hline Female & 2 & 66.7 \\
\hline Unilateral & Laterality of Eye & 33.3 \\
\hline Bilateral & 2 & \\
\hline
\end{tabular}




\begin{tabular}{|c|c|c|}
\hline & 3 & $100.00 \%$ \\
\hline \multicolumn{2}{|c|}{ IOP Category } \\
\hline $0-15 \mathrm{mmHg}$ & 2 & 66.7 \\
\hline $16-30 \mathrm{mmHg}$ & 1 & 33.3 \\
\hline
\end{tabular}

Table 3: Demographic and eye characteristics of respondents with Pterygium $(\mathrm{N}=5)$.

\begin{tabular}{|c|c|c|}
\hline Demographic Variables & Frequency & Percentage (\%) \\
\hline \multicolumn{3}{|c|}{ Age Category } \\
\hline$<30$ years & 1 & 20 \\
\hline $30-39$ years & 1 & 20 \\
\hline $40-49$ years & 3 & 60 \\
\hline \multicolumn{3}{|c|}{ Sex } \\
\hline Male & 2 & 40 \\
\hline Female & 3 & 60 \\
\hline \multicolumn{3}{|c|}{ Laterality of Eye } \\
\hline Unilateral & 4 & 80 \\
\hline Bilateral & 1 & 20 \\
\hline \multicolumn{3}{|c|}{ Visual Acuity } \\
\hline$>6 / 18$ & 4 & 80 \\
\hline $6 / 18-6 / 36$ & 1 & 20 \\
\hline \multicolumn{3}{|c|}{ IOP } \\
\hline $0-15 \mathrm{mmHg}$ & 5 & 100 \\
\hline
\end{tabular}

\section{Discussion}

With the prevailing economic difficulties in Nigeria, free medical outreaches are becoming increasingly popular and attract large numbers of people both in rural and urban settings. The prevalence of pterygium and pingueculum in this study were 5.0\% and 3.0\% respectively. This prevalence of pterygium appears low compared to some studies conducted in Nigeria $[3,10,21]$ and overseas but is also higher than the findings in Abonnema, a riverine community in South-south Nigeria (2.8\%) [9] Iran (1.3\%) [23] and Saudi Arabia $(0.074 \%)[24]$. Its noteworthy that many of the studies in Nigeria were hospital based unlike ours and the study at Abonnema which were community-based. The prevalence of pingueculum is also quite low when compared to other studies [11-15].

The prevalence of pterygium varies widely from one place to the other due to a complex interplay of environmental and other risk factors [13]. It has a worldwide distribution but is common in arears that lie within a geographical latitude from 40 degrees North to 40 degrees South of the equator with less than $2 \%$ prevalence in areas above 40 degrees North $(17,25)$ In this series, the prevalence of both pterygium and pingueculum were highest in the 40-49 years age group which agrees with the observation that the prevalence of pterygium and pingueculum both increase with increasing age [8]. Some studies state that pterygium is more prevalent among males [24] as Monsudi 11 discovered in Birnin Kebbi (M: F = 60.2\%: $39.8 \%$ ), but it does not agree with the findings here (M: $\mathrm{F}=40 \%$ : $60 \%$ ). Our higher prevalence in females agrees with the findings of
Chukwuka [9] and Ukponmwan [20] in south-south Nigeria. Also, Zhong [25] in China found that females appear to be more susceptible to pterygium, and his observed prevalence of pterygium among females was $27.3 \%$ out of a total prevalence of $39.0 \%$.

In the study by Monsudi [11], the peak prevalence of pterygium occurred in the 30-39 years age group and considering their occupations, pterygium was commonest in housewives (31.6\%) and civil servants (26.5\%) compared to farmers (16\%), business men/ traders (14\%) and others. This does not agree with the theoretical basis for the development and progression of pterygia. The peak age incidence was also in the third and fourth decades in studies performed on motorcycle riders in Eastern Nigeria [10,21] and welders [12] in Ile-Ife, Nigeria. Professional motorcycle driving (known as 'Okada' in Nigeria) is a popular form of transportation that is a source of employment for many young men in rural and semi-urban communities. Ukponmwan [21] compared the prevalence of pingueculum and pterygium in 144 professional male motorcycle drivers in Benin city, South-south Nigeria with 114 controls who were male indoor workers and found that the prevalence of pingueculum was $25.7 \%$ in the motorcycle drivers compared to $21.05 \%$ in the indoor workers; and the prevalence of pterygium was $12.5 \%$ in the professional motorcyclists compared to $7.9 \%$ in the controls, Also wearing of face caps/hats was found to have a protective effect from development of pinguecula and pterygium but wearing of sunglasses was not, probably because of the lower quality and cheaper types readily available locally which may not 
have ultraviolet protection but can keep wind and some particles away from the eyes They recommended that professional motorcycle transporters should be educated about the importance of wearing protective goggles and caps/brimmed hats.

Although in the traditional African setting women are less likely to be involved in outdoor activities, the higher female prevalence in this study could be attributed to the fact that the study population showed a marked female preponderance, as was also the case in Abonnema- a riverine town in Rivers state where only 3 (M:F $=1: 2$ ) out of 107 people seen were diagnosed to have pterygium in another much publicized free medical outreach. This may be due to a higher health-seeking behaviour in these females or to scarce personal income in them making them more desirous of aid. In a semi-urban population like this, the people are mostly farmers and traders and may not be aware of the need to undertake protective measures from the effect of the ultraviolet radiation.

A reduction in the visual acuity of $6 / 18$ in the better eye was found in one subject (20\%), and this was probably due to the astigmatic effect of pterygium. Lawal et al in Northern Nigeria [26] demonstrated an improvement in visual acuity and reduction in induced astigmatism after pterygium excision. This study is limited by the lack of a more detailed history from the subjects including their occupation, educational level, amount of daily outdoor time, awareness and use of protective items and the absence of a slit lamp for accurate grading of the pterygia. Also, a much larger scale study covering the entire community is important as it will be interesting to compare the results to those of Osuji [27] where pterygium had a prevalence of $15.2 \%$ next to glaucoma and cataract (with a combined prevalence of almost 50\%) in an entire population screening exercise. Although the results obtained here are significantly higher than that from Abonnema which is in the same South-south geopolitical zone, further research is needed to elucidate the protective effect if any of the riverine location therefore our results are very useful for planning future prevention of blindness programmers in the state.

\section{Conclusion and Recommendations}

The prevalence of pterygium is $5 \%$ and that of pingueculum is $3 \%$ in Eneka community. Pterygium was positively associated with older age. Since advanced pterygia can result in visual impairment and blindness, it is important to publicize some preventive measures to diminish the prevalence of pterygium, such as suggesting people wear a hat and/or sunglasses with beta-irradiation protection whenever they are outside in the hot tropical sunshine, educating farmers and other outdoor workers to raise their awareness for pterygium, and providing surgical services when pterygium excision is required.

\section{Acknowledgement}

None.

\section{Conflicts of Interest}

No conflict of interest.

\section{References}

1. Liang K, Jiang Z, Ding BQ Cheng P, Huang DK, et al. (2011) Expression of cell proliferation and apoptosis biomarkers in pterygia and normal conjunctiva. Mol Vis 17: 1687-1693.

2. Zheng K, Cai V, Jhanji V, Chen H (2012) Comparison of pterygium recurrence rate after limbal conjunctival autograft transplantation and other techniques: Meta-analysis. Cornea 31(12): 1422-1427.

3. Ogbonnaya CE (2009) Spectrum of eye diseases at the Ebonyi State University Teaching Hospital, Abakaliki, Nigeria, Africa 8: 65-69.

4. Lucas RM, McMichael AJ, Armstrong BK (2008) Estimating the global disease burden due to ultraviolet radiation exposure. Int J Epidemiol 37: 654-667.

5. Rezvan F, Hashemi H, Emamian MH, Kheirkhah A, Shariati M, et al. (2012) The prevalence and determinants of pterygium and pinguecula in an urban population in Shahroud, Iran. Acta Med Iran 50(10): 689696.

6. Droutsas, Sekundo W (2010) Epidemiology of pterygium: a review. Ophthalmologe 107(6): 511-516.

7. Anbesse DH, Kassa T, Kefyalew B, Tasew A, Atnie A, et al. (2017) Prevalence and associated factors of pterygium among adults living in Gondar city, Northwest Ethiopia. PLoS ONE 12(3): e0174450.

8. Wanzhen Jiao, Chengchao Zhou, Ting Wang, Shaoyuan Yang, Hongsheng Bi, et al. (2014) Prevalence and Risk Factors for Pterygium in Rural Older Adults in Shandong Province of China: A Cross-Sectional Study BioMed Research International, p. 1- 8.

9. Chukwuka IO, Chinawa EN, Ejele IO (2017) Ocular Morbidity Pattern in Abonnema, Akoku -Toru local government area of Rivers State. Annals of Biomedical Sciences 16(2): 133-139.

10. Achigbu EO, Ezepue UF (2014) Prevalence and severity of pterygium among commercial motorcycle riders in South Eastern Nigeria. Ghana Med J 48: 153-157.

11. Monsudi KF, Azonobi IR, Olatunji FO, Saka ES (2015) Prevalence of pterygium in a tertiary hospital in North-Western Nigeria. J Chitwan Med Col 5(13): 46-51.

12. Iyiade A, Omotoye Olusola J (2012) Pattern of eye diseases among welders in a Nigeria community. Afr Health Sci 12(2): 210-216.

13. Asokan R, Venkatasubbu RS, Velumuri L, Lingam V, George R (2012) Prevalence and associated factors for pterygium and pinguecula in a South Indian population. Ophthalmic Physiol Opt 32(1): 39-44.

14. Le Q Xiang J, Cui X, Zhou X, Xu J (2015) Prevalence and associated factors of pinguecula in a rural population in Shanghai, Eastern China. Ophthalmic Epidemiol 22(2): 130-138.

15. Viso E, Gude F, Rodríguez Ares MT (2011) Prevalence of pinguecula and pterygium in a general population in Spain. Eye 25(3): 350-357.

16. Buchelli AI, Corva DC (2009) Prevalence of pathologies of anterior segment in afro Colombian population: Optometry facuty. Cont Lens Anterior Eye 39(6): 466-470.

17. Esposito E, Correa L, Suarez MF (2014) Comparative study between climatic spheroidal keratopathy with pinguecula android pterygium in the Patagonia Region Asociaton for research in Vision Argentina.

18. Ginger Eke HA, Ogbonnaya CE, Ezisi CN (2018) PTERYGIUM: Recent trends and perspectives a review of pathogenesis and current management options. Niger J Ophthalmol 26: 89-98.

19. Pan Z, Cui J, Shan G, Chou Y, Pan L, et al. (2019) Prevalence and risk factors for pterygium: a cross-sectional study in Han and Manchu ethnic populations in Hebei, China. BMJ Open 9(2): e025725.

20. Hassan Hashemi Mehdi, Khabazkhoob Abbasali, Yekta, JafarzadehpourHadi, OstadimoghaddamHaleh, et al. (2017) The prevalence and determinants of pterygium in rural areas. Journal of current Ophthalmology 29: 194-198.

21. Ukponmwan CU, Dawodu OA, Edema OF, Okojie O (2007) Prevalence of pterygium and pingueculum among motorcyclists in Nigeria. East Afr Med J 84(11): 516-521. 
22. LeiLiu, JingyangWu, JinGeng, ZheYuan, DeshengHuang (2013) Geographical prevalence and risk factors for pterygium: a systematic review and meta-analyisis. BMJOpen 3: e003787.

23. Fotouhi A, Hashemi H, Khabazkhoob M, Mohammad K (2009) Prevalence and risk factors of pterygium and pinguecula: The Tehran eye study. Eye (Lond) 23: 1125-1129.

24. Alqahtani JM (2013) The prevalence of pterygium in Alkhobar: A hospital-based study. J Family Community Med 20(3): 159-161.

25. Zhong H, Cha X, Wei T, Lin X, Li X, et al. (2012) Prevalence of and risk factors for pterygium in rural adult Chinese populations of the Bai nationality in Dali: the Yunnan Minority Eye Study. Invest Ophthalmol Vis Sci 53: 6617-6621.

26. Lawan A, Hassan S, Ifeanyichukwu EP, Yahaya HB, Sani RY, et al. (2018) Astigmatic effect of pterygium in a tertiary Hospital in Kano, Nigeria. Ann Afr Med 17(1): 7-10.

27. Osuji SC, Onwukwe NA, Oboh RA, Odo HC (2020) Pattern of Eye Diseases in a Rural Community of Enugu, Nigeria. Acta Scientific Medical Science 4(1): 64-68. 